\title{
Growth curves on females of the Caracu breed
}

\section{Curvas de crescimento de fêmeas da raça Caracu}

\author{
Raphael Patrick Moreira ${ }^{1 *}$; Maria Eugênia Zerlotti Mercadante ${ }^{2}$; Victor Breno Pedrosa ${ }^{3}$; \\ Joslaine Noely dos Santos Gonçalves Cyrillo²; Wignez Henrique ${ }^{2}$
}

\begin{abstract}
The objective of the study was to analyze nonlinear models that best fit the growth of Caracu cows. The experiment was conducted at the Instituto de Zootecnia, Centro APTA Bovinos de Corte, Sertãozinho, SP. Data of weight at birth to 63 months of age, from 500 females of the Caracu breed were used. The mean weight at birth (BW), weaning weight (W7), weight at 26 months (W26) and weight at 63 months (W63) were, respectively, $32 \mathrm{~kg}, 198 \mathrm{~kg}, 354 \mathrm{~kg}$ and $488 \mathrm{~kg}$, providing an average daily gain (ADG) of $0.241 \mathrm{~kg} /$ day. The nonlinear models used were: Brody, Von Bertalanffy, Logistic and Gompertz. All of the models tended to describe accordingly the growth curve of these animals, but, according to the mean square residual and coefficient of determination adopted to select the most appropriate model, Brody showed the best fit. All models presented a high and negative correlation between the A and $\mathrm{k}$ parameters, indicating that the most precocious animals are less likely to reach elevated weights at 63 months of age. The effect of year of birth significantly affected $(\mathrm{P}<0.01)$ the parameters $\mathrm{A}$ and $\mathrm{k}$, concluding that the animal selection based on growth traits favored the increase of mature weight and growth precocity over the generations.
\end{abstract}

Key words: Nonlinear models. Precocity. Weight development.

\section{Resumo}

O objetivo do estudo foi analisar os modelos não-lineares que melhores se ajustam ao crescimento de fêmeas da raça Caracu. O experimento foi conduzido no Instituto de Zootecnia, Centro APTA Bovinos de Corte, Sertãozinho, SP. Dados de peso ao nascimento até os 63 meses de idade de 500 fêmeas da raça Caracu foram utilizados. A media de peso ao nascer (PN), peso a desmama (P7), peso aos 26 meses (P26) e peso aos 63 meses (P63) foram, respectivamente, de $32 \mathrm{~kg}, 198 \mathrm{~kg}, 354 \mathrm{~kg}$ e $488 \mathrm{~kg}$, fornecendo um ganho médio diário (GMD) de $0,241 \mathrm{~kg} /$ dia. Os modelos não-lineares utilizados foram: Brody, Von Bentarlanffy, Logístico e Gompertz. Todos os modelos descreveram adequadamente a curva de crescimento destes animais, porém de acordo com o quadrado médio do resíduo e coeficiente de determinação, adotados para escolha do modelo mais apropriado, Brody mostrou o melhor ajuste. Todos os modelos apresentaram alta e negativa correlação entre os parâmetros A e k, indicando que animais mais precoces possuem menor probabilidade de atingir pesos mais elevados aos 63 meses de idade. $\mathrm{O}$ efeito de ano de nascimento afetou significativamente $(\mathrm{P}<0,01)$ os parâmetros $\mathrm{A}$ e $\mathrm{k}$, sugerindo que a seleção dos animais com base em características de crescimento favoreceu o aumento do peso adulto $\mathrm{e}$ a precocidade, com o passar das gerações.

Palavras-chave: Desenvolvimento ponderal. Modelos não lineares. Precocidade.

\footnotetext{
${ }^{1}$ Discente do Curso de Graduação em Zootecnia, Universidade Estadual de Ponta Grossa, UEPG, Ponta Grossa, PR, Brasil. Bolsista CNPq - PIBIC. E-mail: raphaelmoreira@zootecnista.com.br

${ }^{2}$ Pesquisadores, Instituto de Zootecnia, Sertãozinho, SP, Brasil.E-mail: mercadante@iz.sp.gov.br; cyrillo@iz.sp.gov.br; wignez@ terra.com.br

${ }^{3}$ Prof. Adjunto, UEPG, Ponta Grossa, PR, Brasil. E-mail: vbpedrosa@uepg.br

* Author for correspondence
} 


\section{Introduction}

According to Battistelli (2012), in 2011 Caracu was the only one of breeds adapted to the tropics with significant space in the Brazilian market of semen, with a sale of 20,000 doses sold in the country. According to Lima et al. (1990), the Caracu has a dual purpose, i.e. it has the potential both for milk production as well as meat. According to evidence of weight gain and crosses with other breeds, the Caracu have shown a high production of meat and have adapted to heat and harsh environments, such as in Central Brazil (MCMANUS et al., 2010).

The relationship between a dependent variable and one or more independent variables can be evaluated through regression models (PEREIRA, 2012). Within this context, are the nonlinear models, which have a good fit to describing animal growth and fewer parameters compared to linear models (SOUZA et al., 2010). These functions serve as a method to describe biological systems, and the parameters have practical interpretations (LOPES et al., 2011). The growth of an animal can be studied by their growth curves, which describes the relationship between the weight and age of the animal (SILVA et al., 2011). Growth knowledge is a subject of interest with regard to providing better efficiency in nutritional management and for the preparation of animal breeding programs that consider growth traits inherent in each cattle breed (TEDESCHI et al., 2000).

Nonlinear models have been applied in studies on the growth of beef cattle in recent decades (TEDESCHI et al., 2000; FORNI et al., 2009), mainly using the Brody, Von Bertalanffy, Logistic or Gompertz models. However, there are no studies that describe the growth of the Caracu, and for this reason, the objective of this study was to analyze the nonlinear models that better fit the growth curve of females of this breed.

\section{Material and Methods}

\section{Data set}

The database considered the females of the Caracu herd from the Zebu and Caracu Cattle Breeding Program, located at the Animal Science Institute - APTA, Sertãozinho, SP. The research unit is localized in the north of São Paulo State (latitude $21^{\circ} 10^{\prime}$ south and longitude $48^{\circ} 5^{\prime}$ west). The climate is tropical with rainy summer and dry winter seasons; furthermore, the predominant pasture is of Panicum maximum and Brachiaria species.

The females were maintained on pasture and weaned at 7 months of age. After weaning, the animals started to receive mineral salt, and at 550 days of age were selected according to their weight to be intended as future dams. The breeding season was formed with up to 25 cows/bull, and lasted around 90 days.

Five hundred females born from 1981 to 2007 were weighted from birth to 63 months, divided into: birth weight (BW), 4 months (W4), 7 months or weaning weight (W7), 14 months (W14), 17 months (W17), 19 months (W19), 26 months (W26), 42 months (W42), 51 months (W51) and 63 months (W63). It is important to mention that at 26 months old the females entered reproductive life, and after this age, the animals were weighted at the beginning of the breeding season, so as to not suffer any influence of factors related to pregnancy.

\section{Best model determination}

For determining the growth curve, the models used were Von Bertalanffy, Brody, Gompertz and Logistic (Table 1) using the following parameters: $\mathbf{Y}$, which is the body weight at the age t; $\mathbf{A}$ is the asymptotic weight; $\mathbf{B}$ is an integration constant related to the initial animal weights. The value of $\mathrm{B}$ is set by the initial values of $\mathrm{Y}$ and $\mathrm{t}$. The parameter $\mathbf{k}$ is interpreted as the mature rate, which is the 
change in weight from birth to maturity and can be consider a speed indicator as the animal approaches adult size. The $\mathbf{m}$ parameter establishes the curve form and therefore determines the proportion in which the asymptotic value (A) is the inflection point of the curve.

Nonlinear models not allowed solving equations directly formed, as occurs in the linear models, which the resolution of the system is dependent on the proper parameters to be estimated. Thus, an iterative process is used to obtain estimates of the parameters, which begins with initial values assigned to its own parameters to be estimated. The sum of the square error is calculated to obtain an updated set of estimates, until they converge to a final vector obtained in the minimum sum of the square error (SARMENTO et al., 2006).

Table 1. General form of nonlinear models.

\begin{tabular}{cc}
\hline Models & General Form \\
\hline Brody & $\mathrm{Y}=\mathrm{A}\left(1-\mathrm{Be}^{-\mathrm{kt}}\right)$ \\
Von Bertarlanffy & $\mathrm{Y}=\mathrm{A}\left(1-\mathrm{Be}^{\mathrm{kt}}\right)^{3}$ \\
Logistic & $\mathrm{Y}=\mathrm{A}\left(1+\mathrm{e}^{-\mathrm{kt}}\right)^{-\mathrm{m}}$ \\
Gompertz & $\mathrm{Y}=\mathrm{Ae}^{\mathrm{Be}-\mathrm{kt}}$ \\
\hline
\end{tabular}

To estimate the parameters we used the Marquardt method modified by the statistical procedure NLIN the Statistical Analysis System (SAS, 2009) with $10^{-8}$ convergence criteria. The criteria used to verify the accuracy of the models were the mean square error (MSE) and the coefficient of determination $\left(\mathrm{R}^{2}\right)$, estimated by adjustments of the nonlinear models.

After choosing the best model, the absolute growth rate (AGR) was calculated, obtained from the first derivative of the fitted model, versus time $(\partial \mathrm{y} / \partial \mathrm{t})$. The AGR is the weight gain obtained per unit of time, which is measured in days for a better representation of the average daily weight gain, estimated along the growth trajectory of Caracu females. Moreover, the effect of the year of birth was evaluated (1981-2007) on the parameters $\mathrm{A}$ and $\mathrm{k}$ of the selected model curve, through the SAS GLM procedure. Pearson's correlations between parameters were estimated by SAS CORR procedure.

\section{Results and Discussion}

Table 2 shows the average weights and standard deviations of the different ages. Weight measurements were performed up to 63 months of age, which resulted in more reliable parameters, as described by Morrow et al. (1978). These authors mention that for beef cattle, weighing starting at 54 months of age gives more accurate estimates, as the adult size is already set, in all breeds, from this time forward. The females presented an average of $32 \mathrm{~kg}$ and $488 \mathrm{~kg}$ for BW and W63, respectively, giving an average daily gain of 0.241 $\mathrm{kg} /$ day.

The parameter A, defining the asymptotic weight, was higher for Brody followed by the Von Bertalanffy, Logistic and Gompertz models (Table $3)$. These results agree with those obtained for the Laguna breed (GBANGBOCHE et al., 2011), which, like the Caracu, is also adapted to the tropics, having very similar characteristics. However, in that study, the values for the parameter A were slightly lower $(127.19 \pm 2.80 \mathrm{~kg})$, indicating that the Laguna breed is a smaller size compared to the Caracu. 
Table 2. Descriptive statistics of birth weight (BW), 4 months (W4), 7 months (W7), 14 months (W14), 17 months (W17), 19 months (W19), 26 months (W26), 42 months (W42), 51 months (W51) and 63 months of age (W63) on females of the Caracu breed.

\begin{tabular}{lcccc}
\hline \multicolumn{1}{c}{ Trait } & Mean & Standard Deviation & Minimum & Maximum \\
\hline WB $(\mathrm{kg})$ & 32 & 4 & 22 & 47 \\
W4 $(\mathrm{kg})$ & 150 & 27 & 72 & 233 \\
W7 $(\mathrm{kg})$ & 198 & 26 & 126 & 286 \\
W14 $(\mathrm{kg})$ & 227 & 41 & 137 & 360 \\
W17 $(\mathrm{kg})$ & 287 & 45 & 171 & 391 \\
W19 $(\mathrm{kg})$ & 303 & 46 & 177 & 433 \\
W26 $(\mathrm{kg})$ & 350 & 49 & 246 & 474 \\
W42 $(\mathrm{kg})$ & 408 & 44 & 300 & 539 \\
W51 $(\mathrm{kg})$ & 460 & 45 & 321 & 612 \\
W63 $(\mathrm{kg})$ & 488 & 56 & 339 & 650 \\
\hline
\end{tabular}

Table 3. Estimates of the parameters, mean square error, coefficient of determination of the studied models on females of the Caracu breed.

\begin{tabular}{ccccc}
\hline Parameter & \multicolumn{4}{c}{ Model } \\
\hline & Von Bertarlanffy & Brody & Gompertz & Logístic \\
\cline { 2 - 5 } B & 488.3 & 514.6 & 480.4 & 473.9 \\
$\mathrm{k}$ & 0.4595 & 0.8840 & 1.7521 & - \\
$\mathrm{m}$ & 0.0586 & 0.0396 & 0.0685 & 0.0810 \\
Mean Square Error (MSE) & - & - & - & 2.4223 \\
Coefficient of Determination $\left(\mathrm{R}^{2}\right)$ & 2185.25 & 1998.18 & 2270.13 & 2352.71 \\
& 0.9773 & 0.9784 & 0.9810 & 0.9792 \\
\hline
\end{tabular}

Lopes et al. (2011), working with Nellore cows, estimated values of $471 \mathrm{~kg}, 358 \mathrm{~kg}, 338 \mathrm{~kg}$ and 310 $\mathrm{kg}$ for parameter A, for Brody, Von Bertalanffy, Gompertz and Logistic, respectively. Through these results, it can be seen that the values between the Caracu and Nellore, although approximate, suggest that the latter breed will achieve the inflection point of the growth curve at a later age, showing that Nellore is more tardy, in terms of muscle growth, compared to Caracu.

Regarding the parameter B (table 3), all models overestimated the initial weights, but the Brody model was the closest to the real average birth weight. In a study of Santa Gertrudis beef cattle, Tholon et al. (2012) estimated parameter B values for Brody, Gompertz and Von Bertalanffy of
$0.9614,1.9574$ and 0.5105 , respectively. In this study, the Gompertz and Von Bertalanffy models overestimated the weight at birth, and Brody underestimated the weight at the same period, but as found here, the model that better estimated the observed values was also Brody. These results support the theory that Brody is the model that most closely matches to the initial weights of beef cattle. The overestimated values for parameter B may be due to the large weight gain between BW and W4, which causes an estimation point well above those expected.

The reported result for the parameter $\mathrm{k}$ defines that the models varied little based on this parameter (table 3). Logistics (0.0810) had the highest value and Brody (0.0396) the smallest, with Von 
Bertalanffy (0.0586) and Gompertz (0.0685) presenting intermediate values. Marinho et al. (2013), studying the Nellore breed, presented k values equal to 0.0022 and 0.0045 with Brody and von Bertalanffy respectively. These values are well below those found in this study, which agrees with the fact that the Bos taurus indicus are later in terms of maturity compared to Bos taurus taurus. According to Pereira (2012), precocity has an extremely important effect on animal puberty and thus, a female who reaches puberty earlier (higher weight gain rate) obviously starts earlier in their reproductive life. This results in maximizing their service life, and also the number of products per cow, allowing, as a consequence, a greater selection intensity. This indicates that the Caracu females can overcome productivity in comparison to Zebu breeds and is recommended to be used in pure mating systems or crossed with other breeds.

Two parameters were assessed jointly to determine the models' adjustment to animal weight, these being the coefficient of determination $\left(\mathrm{R}^{2}\right)$ and the mean square error (MSE). As we can see in Table 3, all models showed high values for $\mathrm{R}^{2}$, highlighting the Gompertz model. However, checking the MSE results, the Brody model showed lower value and hence the nearest desired. Thus, despite all models adequately describing the growth of the animal, the Brody and Gompertz models can be considered as the best predictors of Caracu females' growth. Nevertheless, in order to choose the model that should be used to predict the growth of animals, we must also take into account the breeders' needs, since some models tend to predict the growth more appropriately in specific periods of the curve.

In his work, Gbangboche et al. (2011), evaluating nonlinear models for females and males of the Laguna breed, cited Brody as the model that presented the best fit to the evaluated data, followed by Gompertz. Through $\mathrm{R}^{2}$ and MSE, these models were the most adequate to describe the growth of the Laguna breed. Furthermore, Belgian Blue animals also showed an adequate fit by Gompertz and Brody, when they assessed the $\mathrm{R}^{2}$, with the same values from 0.819 to 0.862 and from 0.821 to 0.862 , respectively (De BEHR et al., 2001). Silva et al. (2004) studied the growth curves of Nellore animals, also finding the best fit for Brody and Gompertz, emphasizing that both models can be used to describe the growth of these animals. However, these authors mentioned that, from a practical point of view, the best choice is Gompertz, since the highest percentage of convergence gave them greater security for experiments involving the estimates of parameters A, B and k. Miguel et al. (2012), studying the Brahma breed, also reported that the Gompertz model showed a better fit to the growth of beef cattle, with a lower MSE and higher $\mathrm{R}^{2}$, compared to the other models. Forni et al. (2009) cited that the Brody and Gompertz models adequately describe the growth of Nellore females, but Brody could best predict the birth weight of these animals, as also observed in this study. This confirms the effectiveness of the Brody and Gompertz models for this genetic group, endorsing the utilization of the same models to predict Caracu growth, and providing more information on a breed poorly studied in Brazil.

Figure 1 shows the predicted growth curves according to the Von Bertalanffy, Brody, Gompertz and Logistic models, along with the average weights observed. Growth was high until weaning, and after this period there was a decline in growth rates due to the absence of suckling and the physiological adaptation of the female to the fiber degradation of pastures.

It is observed that all models showed a similar performance. All models overestimated the BW, however Brody estimated results closer to those observed, agreeing with the results obtained by Silva et al. (2011) and Forni et al. (2009). After 4 months until 13 months all models underestimated the weights, and after this period until 17 months the weights were overestimated. From W17 to W26 all models adequately described the growth curves 
of Caracu. At the end of the curve, the models, once more, underestimated the results, according to findings by Marinho et al. (2013). Due to the better adjustment of the Brody and Gompertz models, they were used to describe the AGR of Caracu females. The AGR was obtained from the first derivative of the equation of the above-mentioned models as a function of time.

Figure 1. Observed and estimated weight, obtained by Von Bertarlanffy, Brody (a); Gompertz, Logistic (b), models on females of the Caracu breed.
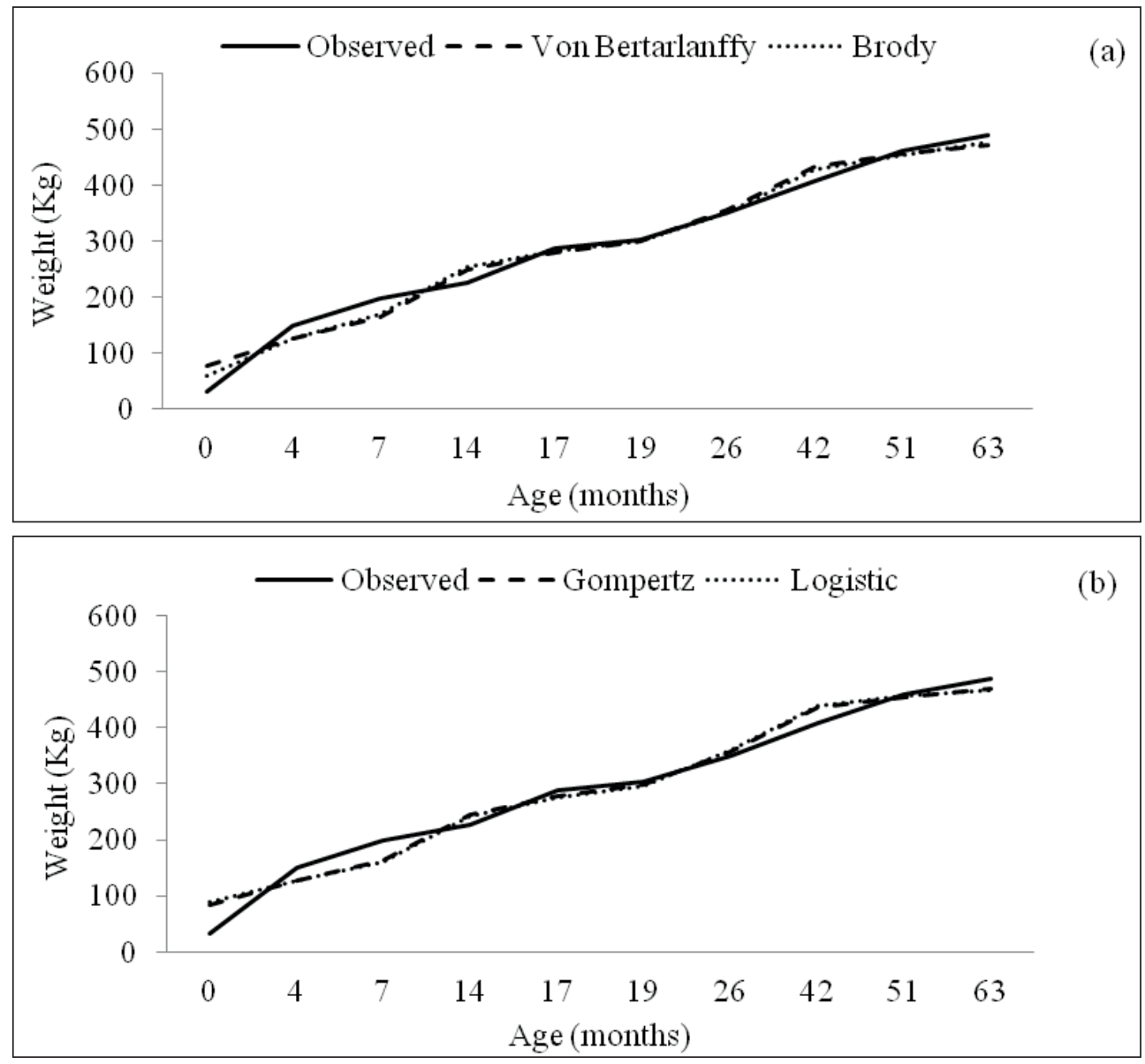

The AGR from Brody (figure 2) has been decreasing since birth, with a value of 570 grams. The rate of decrease in the AGR was high up to 25 months and from this age the rate begins to stabilize with values close to zero. The comportment of the AGR curve for the Brody function was similar to the results presented by Marinho et al. (2013), who cite that the AGR constant decreases, reaching its maximum point at birth period, since the model arrangement that they utilized does not have an inflection point (m) of the curve. Figure 3 shows the performance of the AGR bythe Gompertz model, in which the growth rate at birth was approximately $0.350 \mathrm{~kg}$ per day, reaching its maximum ( 0.400 kilograms per day) at 200 days of age, which coincides with the time of the weaning period. After this period, the AGR decreases until it stabilizes at approximately $0.100 \mathrm{~kg}$ per day, around 4 years old of age. It is important to note that weight gain in females should be raised to reduce 
the age at first conception, favoring the early onset of reproductive life. However, we should be very careful about the fact that a higher daily weight gain not only reduces the age of maturity, but can also impair the reproductive rate and raise the cost per animal slaughtered (FORNI et al., 2007).

Pearson's correlations between parameters $\mathrm{A}$ and $\mathrm{k}$ were high and negative, with values of
$-0.8065,-0.9066,-0.7494$ and -0.6958 between the parameters estimated by the Von Bertalanffy, Brody, Gompertz and Logistic models, respectively. These values indicate that animals that have a high growth rate tend to have smaller asymptotic weights compared to those with low growth rates, which is consistent with the results obtained by other authors (PAZ et al., 2004; LOPES et al., 2011; THOLON et al., 2012).

Figure 2. Absolute growth rate estimated by the Brody function on females of the Caracu breed.

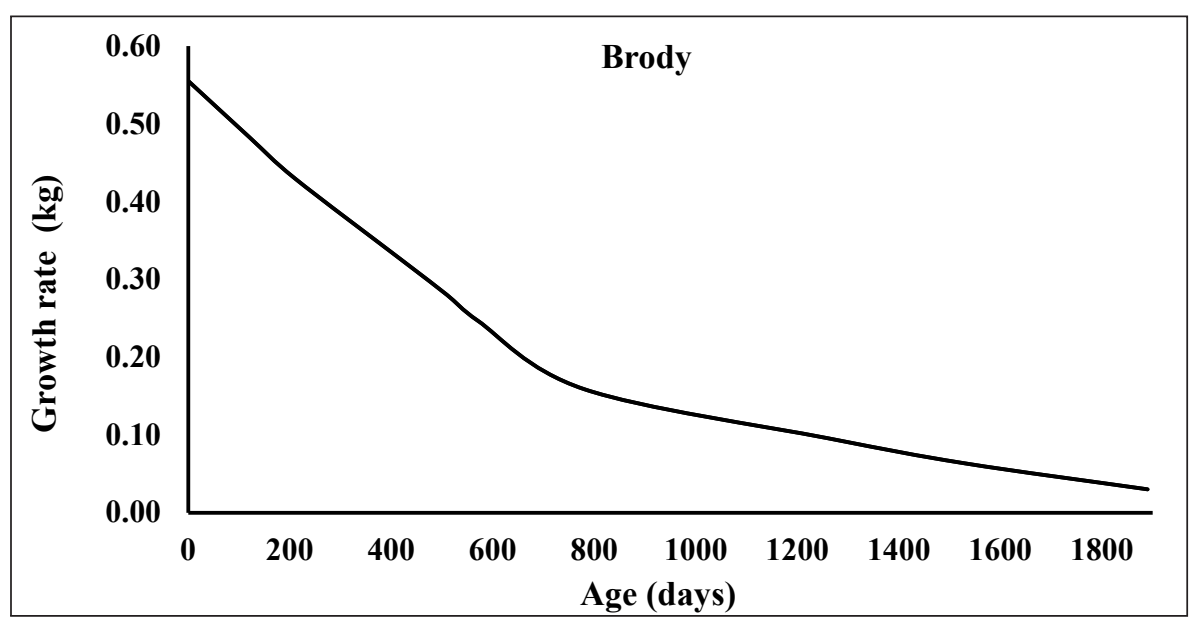

Figure 3. Absolute growth rate estimated by the Gompertz function on females of the Caracu breed.

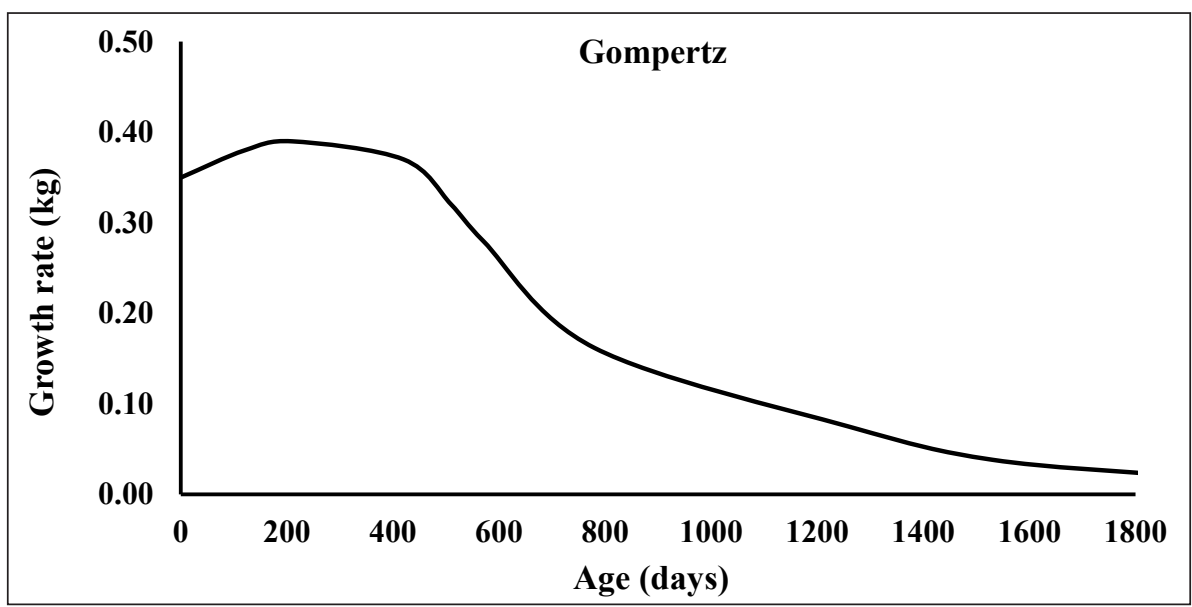

The effect of year of birth significantly influenced $(\mathrm{P}<0.01)$ the parameters $\mathrm{A}$ and $\mathrm{k}$ of the Brody and Gompertz models, as described by Silva et al. increase in adult weight and rise in animal precocity.
(2004). This result corroborates the fact that the selection, nutrition and other factors influenced an 


\section{Conclusion}

The Brody and Gompertz models presented the best fit of the growth curves of Caracu females from birth to mature age. Moreover, a negative correlation between the parameters $\mathrm{A}$ and $\mathrm{k}$ was achieved, inferring that animals with lower adult weight tend to have higher precocity rates.

\section{Acknowledgment}

The authors thank the Instituto de Zootecnia (IZ) for granting the data for this study.

\section{Ethics Committee and Biosafety}

The experiment was conducted in accordance with animal welfare guidelines agreeing with the State of São Paulo law number 11977.

\section{Referências}

BATTISTELLI, J. V. F. Alternativas de cruzamento utilizando raças taurinas adaptadas ou não sobre matrizes nelore para a obtenção de novilhos precoces. Dissertação (Mestrado em Ciência Animal) - Universidade Federal do Mato Grosso do Sul, Campo Grande, 2012.

DE BEHR, V.; HORNICK, J. L.; CABARAUX, J. F.; ALVAREZ, A.; ISTASSE, L. Growth patterns of Belgian Blue replacement heifers and growing males in commercial farms. Livestock Production Science, Madrid, v. 71, n. 2, p. 121-130, 2001.

FORNI, S.; PILES, M.; BLASCO, A.; VARONA, L.; OLIVEIRA, H. N.; LOBO, R. B.; ALBUQUERQUE, L. G. Analysis of beef cattle longitudinal data applying a nonlinear model. Journal of Animal Science, Champaign, v. 85, n. 12, p. 3189-3197, 2007.

Comparison of different nonlinear functions to describe Nelore cattle growth. Journal of Animal Science, Champaign, v. 87, n. 2, p. 496-506, 2009.

GBANGBOCHE, A. B.; ALKOIRET, T. I.; TOUKOUROU, Y.; KAGBO, A.; MENSAH, G. A. Growth curves for different body traits of Lagune cattle. Journal of Animal Science, Champaign, v. 5, n. 2, p. 1724, 2011.
LIMA, M. L. P.; BONILHA NETO, L. M.; RAZOOK, A. G. O. O gado Caracu. Revista dos Criadores, São Paulo, p. 28-30, 1990.

LOPES, F. B.; SILVA, M. C.; MARQUES, E. G.; FERREIRA, J. L. Ajuste de curvas de crescimento em bovinos Nelore da região Norte do Brasil. Revista Brasileira de Saúde e Produção Animal, Salvador, v. 12, n. 3, p. 607-617, 2011.

MARINHO, K. N. S.; FREITAS, A. R.; FALCÃO, A. J. S.; DIAS, F. E. F. Nonlinear models for ditting growth curves of Nellore cows reared in the Amazon Biome. Revista Brasileira de Zootecnia, Viçosa, MG, v. 42, n. 9, p. 645-650, 2013.

MCMANUS, C.; RIBEIRO, R; SEIXAS, L.; MELO, C. A raça Caracu. INCT: Informação Genético- Sanitária da Pecuária Brasileira. 2010. Disponível em: <http:// inctpecuaria.com.br/images/informacoes-tecnicas/serie tecnica_raca_caracu.pdf $>$. Acesso em: 21 set.

MIGUEL, J. A.; MELENDEZ, S. J.; ASENJO, B.; BONILLA, L. M.; CIRIA, J. Growth modeling of castrated Brahman males raised in tropical conditions and born in different seasons. Ciencia e Investigación Agraria, Santiago, v. 39, n. 2, p. 279-288, 2012.

MORROW, R. E.; McLAREN, J. B.; BUTTS, W. T. Effect of age on estimates of bovine growth-curve parameters. Journal of Animal Science, Champaign, v. 47, n. 2, p. 352-357, 1978.

PAZ, C. C. P.; PACKER, I. U.; FREITAS, A. R.; TAMBASCO-TALHARI, D.; REGITANO, L. C. A.; ALENCAR, M. M. Ajuste de modelos não-lineares em estudos de associação entre polimorfismo genético e crescimento em bovinos de corte. Revista Brasileira de Zootecnia, Viçosa, MG, v. 33, n. 6, p. 1416-1425, 2004.

PEREIRA, J. C. C. Melhoramento genético aplicado à produção animal. 6. ed. Belo Horizonte: FEPMVZ editora , p. 7-36, 2012.

SARMENTO, J. L. R.; REGAZZI, A. J.; SOUZA, W. H.; TORRES, R. A.; BREDA, F. C.; MENEZES, G. R. O. Estudo da curva de crescimento de ovinos Santa Inês. Revista Brasileira de Zootecnia, Viçosa, MG, v. 35, n. 2, p. 435-442, 2006.

SILVA, F. L.; ALENCAR, M. M.; FREITAS, A. R.; PACKER, I. U.; MOURÃO, G. B. Curvas de crescimento em vacas de corte de diferentes tipos biológicos. Pesquisa Agropecuária Brasileira, Brasília, v. 46, n. 3, p. 262-271, 2011. 
SILVA, N. A. M.; AQUINO, L. H.; SILVA, F. F.; OLIVEIRA, A. I. G. Curvas de crescimento e influência de fatores não-genéticos sobre as taxas de crescimento de bovinos da raça Nelore. Ciência e Agrotecnologia, Lavras, v. 28, n. 3, p. 647-654, 2004.

SOUZA, L. de A.; CAIRES, D. N.; CARNEIRO, P. L. S.; MALHADO, C. H. M.; MARTINS FILHO, R. Curvas de crescimento em bovinos da raça Indubrasil criados no Estado de Sergipe. Revista Ciência Agronômica, Fortaleza, v. 41, n. 4, p. 671-676, 2010.

STATISTICAL ANALYSIS SYSTEM - SAS. User's guide. Version 9. Cary: SAS Institute, 2009. CD-ROM.
TEDESCHI, L. O.; BOIN, C.; NARDON, R. F.; LEME, P. R. Estudo da curva de crescimento de animais da raça Guzerá e seus cruzamentos alimentados a pasto, com e sem suplementação. 1. Análise e seleção das funções não-lineares. Revista Brasileira de Zootecnia, Viçosa, MG, v. 29, n. 2, p. 630-637, 2000.

THOLON, P.; PAIVA, R. D. M.; MENDES, A. R. A.; BARROZO, D. Utilização de funções lineares e não lineares para ajuste do crescimento de bovinos Santa Gertrudis, criados a pasto. ARS Veterinaria, Jaboticabal, v. 28, n. 4, p. 234-239, 2012. 
